Research Article

\title{
A Quantitative Study on the Benefit of Various Waste Classifications
}

\author{
Jiahe Zhang $(\mathbb{D}$, Zhenying Zhang $(\mathbb{D}$, Jiayue Zhang $(\mathbb{D}$, Guoyang Fan $\mathbb{( D}$, and Dazhi Wu $(\mathbb{D}$ \\ School of Civil Engineering and Architecture, Zhejiang Sci-Tech University, Hangzhou 310018, China \\ Correspondence should be addressed to Zhenying Zhang; zhangzhenyinga@163.com
}

Received 2 December 2020; Accepted 13 May 2021; Published 27 May 2021

Academic Editor: Hui Yao

Copyright (c) 2021 Jiahe Zhang et al. This is an open access article distributed under the Creative Commons Attribution License, which permits unrestricted use, distribution, and reproduction in any medium, provided the original work is properly cited.

Chinese economic development has continuously increased national municipal solid waste (MSW) output. However, the existing MSW classification method is insufficient and exacerbates several urgent problems. There are many factors to consider in Chinese waste classification (population, MSW production, food waste content, water content, economy, environment, and waste disposal methods). Based on research and analysis, MSW classification should highlight and implement treatment methods that focus on incineration, the distinct treatment of kitchen waste, and landfills as a waste disposal supplement. MSW is divided into five categories: kitchen waste, incineration, recyclable, hazardous waste, and other waste. Using economic benefit analysis, life cycle assessment, and radar chart analysis, a quantitative study is conducted on the classification methods of MSW used in Germany, the US, the UK, Sweden, Japan, China, and this study. The results indicate that a more refined classification can effectively improve many aspects of MSW management, especially regarding economic and environmental benefits, which are significantly affected. Effective MSW management can reduce the cost of waste disposal by $69.4 \%$ and greenhouse gas and acidic substance emissions and increase the energy utilisation rate four fold. This research is of great significance to environmental protection and the development of a circular economy and provides a reference for the management of MSW.

\section{Introduction}

The Chinese economy and population are displaying continuous growth trends. The Chinese municipal solid waste (MSW) output is increasing yearly, and the classification and disposal of MSW have become an area of concern. In 2018, total Chinese MSW production reached 22.8 million tons [1]. MSW management is a challenge facing society, and developing methods for managing MSW efficiently, economically, and environmentally is important for promoting sustainable urban development. Classification is a core component of the MSW management system. The purpose of MSW classification is to improve the waste utilisation rate, reduce the amount of landfill, and reduce the waste disposal cost. Therefore, the classification of MSW will affect the economic, environmental, and waste treatment benefits [2]. Landva et al. [3] classified MSW into organic and inorganic materials, while Thomas et al. [4] classified MSW into soillike and nonsoil-like materials. Research only considered the nature of waste. Sharholy et al. [5] studied the impact of the Indian MSW treatment process on the waste classification method and concluded that landfill disposal waste is limited to nonbiodegradable waste, inert waste, and other wastes unsuitable for recycling or nonbiological treatment. Gentil et al. [6] studied the effects of various waste treatment process ratios on greenhouse gas (GHG) emissions. Denmark and Germany focused on incineration. France used three treatment methods fairly evenly (36\% incineration, $34 \%$ landfill, and 30\% resource recovery). Greece, Britain, and Poland focused on landfills. The study found that countries utilising incineration as the primary treatment method emitted less GHG emissions than those using landfills as the primary treatment method. Therefore, a waste classification method should separate incineration materials to facilitate the waste treatment process and reduce pollution. Zhang et al. [7] studied the classification method of Chinese MSW, with the economy (waste-to-energy/WTE) (compost recovery rate and income-cost ratio) as the 
primary influencing factor. The classified MSW (divided into kitchen waste, general waste, and ash) was compared with the unclassified MSW. The research illustrated that the compost recovery rate, cost-benefit ratio, productivity, and nutrient content of the compost significantly improved after classification. Zhou et al. [8] studied the thermal chemical characteristics of different MSW components (e.g., vegetables, starch food, orange peel, wood waste, printing paper, cellulose, PVC, PET, PE/PP, PS, and rubber). The study demonstrated that combustible waste is generally classified into six physical categories: food residue, wood waste, paper, textiles, plastic, and rubber; However, the calorific value of each component differs. It is possible to redefine typical components for WTE research. Chang et al. [9] analyzed various characteristics of MSW (e.g., physical, chemical, combustion, and biological and degradable characteristics) and concluded that household waste can be divided into organic waste, inert waste, hazardous waste, and other harmless waste. $\mathrm{Gu}$ et al. [10] also discussed the MSW classification method in China according to the MSW characteristics (e.g., large organic waste accounting for $71 \%$ of the total waste). They proposed that kitchen and recyclable wastes should be collected separately, and the classification method should be concise and clear. Liikanen et al. [11] studied a waste classification method WTE as the main influencing factor. Considering the composition of MSW in Finland (the waste was characterised by a large amount of organic waste, accounting for $40 \%$ of the total), yard waste was subdivided into sticks, branches, and other yard waste, and the plastic packaging was subdivided into dense and film types to achieve the greatest recycling economic benefits. Dada et al. [12] studied a MSW classification method in Africa WTE as the main influencing factor. They concluded that compacted waste contains a higher proportion of organic waste that can produce more renewable energy (biogas). Girotto [13] studied the MSW classification method in Brazil WTE as the primary influencing factor. The study demonstrated that if a MSW component contains more than $50 \%$ organic waste, more than $15 \%$ inert waste, or its calorific value is less than $2.326 \mathrm{MJ} / \mathrm{kg}$, then incineration may not be the optimal disposal method; the waste may be more suitable for anaerobic digestion and composting. AIHameedi et al. [14] classified MSW into environmental waste, degradable waste, nondegradable waste, and toxic waste according to its nature. The MSW classification methods of several cities in China [15-17] are displayed in Table 1.

Based on the literature, most researchers have only considered a single influencing factor on MSW classification. Moreover, few studies calculate the value of each factor produced by different classification schemes. However, the classification of MSW is complicated. With large waste production and complex composition, overlooking multiple factors will result in poor classification schemes, low economic and environmental benefits, and low public enthusiasm. This study refers to previous research on MSW classification methods and combines the characteristics of abundant MSW kitchen waste in China [18] with high water content. The influences of many factors such as the economy, environment, and waste treatment are considered, especially the connection between source classification and waste treatment, and a new method for the classification of MSW in China is proposed. In addition, this study quantitatively analyzed these factors to provide references for China's waste management.

\section{Classification and Methods}

\subsection{Classification}

2.1.1. Comparison Sample Selection. To better analyze the difference in benefits produced by different MSW classification, in this study the classification schemes of six countries were selected: Germany, the US, the UK, Sweden, Japan, and China. Each benefit value was quantitatively calculated with the scheme proposed in this paper. The sample selection mainly considered factors such as geographical, economic, and cultural factors because these factors will affect the setting of the MSW classification scheme. The classification methods of MSW in several countries are displayed in Table 2.

MSW is primarily composed of kitchen waste, yard waste, paper and cardboard, textiles, leather, rubber, plastic, glass, wood, metal, and other materials. The composition of MSW in multiple countries is displayed in Figure 1 [25-30]. As illustrated in Figure 1, the proportion of kitchen waste in China is $54.92 \%$, which is substantially higher than that of the other countries. The primary reasons for this are as follows: first, as the Chinese economy continues to develop, living standards are constantly improving; people pay greater attention to food and food type, and there is a surplus of food. Second, Chinese residents have unique eating habits (i.e., hot pot, soup, etc.) and a unique drinking culture (i.e., banquets). Third, the Chinese take-out food model, where fresh fruits, vegetables, and meat are typically provided to consumers in a small amount of packaging, results in a high proportion of food waste [31]. Figure 1 also illustrates that the UK has the highest yard waste proportion of up to $20 \%$. This is because many families in the UK have their own yards and they often trim their gardens and remove fallen leaves. Japan has the highest proportion of paper (including cardboard) waste at $34.6 \%$. This is predominately because paper packaging has replaced plastic packaging, and incineration is the primary waste treatment method in Japan. Paper waste can increase the overall calorific value of incineration, which is safer and more efficient than plastic incineration.

2.1.2. Proposal of a New MSW Classification in Zhejiang, China. Zhejiang is in the Yangtze River Delta area at the centre of east China (approximately $27^{\circ} 02^{\prime}-31^{\circ} 11^{\prime} \mathrm{N}$, $\left.118^{\circ} 01^{\prime}-123^{\circ} 10^{\prime} \mathrm{E}\right)$. In 2019 , the total population of the province was 58.5 million, with an official urban population of 39.5 million. The per capita gross domestic product is $\$ 15,601$ in 2019. The economic level of Zhejiang province has developed rapidly, while the degree of economic development within the province has remained stable. The financial, commerce, and cultural industries are the three major 
Table 1: MSW classification schemes in China.

\begin{tabular}{lc}
\hline Classification schemes & Cities \\
\hline $\begin{array}{l}\text { Six groups (recyclables, kitchen waste, hazardous waste, decoration wastes, } \\
\text { bulky waste, and other) }\end{array}$ & Qingdao \\
$\begin{array}{l}\text { Five groups (a) (recyclables, kitchen waste, hazardous waste, bulky waste, } \\
\text { and other) }\end{array}$ & Fuzhou \\
$\begin{array}{l}\text { Five groups (b) (recyclables, kitchen waste, hazardous waste, compostable, } \\
\text { and other) }\end{array}$ & Chengdu \\
$\begin{array}{l}\text { Four groups (a) (recyclables, hazardous waste, wet waste, and dry waste) } \\
\text { Four groups (b) (recyclables, kitchen waste, hazardous waste, and other) }\end{array}$ & Guangzhou, Jinan, Tianjin, Shenzhen, Hangzhou, Ningbo, \\
$\begin{array}{l}\text { Four groups (c) (recyclables, kitchen waste, hazardous waste, and } \\
\text { nonrecyclable) }\end{array}$ & Dalian, and Nanjing \\
$\begin{array}{l}\text { Four groups (d) (recyclables, hazardous waste, nonrecyclables, and glass) } \\
\text { Three groups (a) (recyclables, kitchen waste, and other) } \\
\text { Three groups (b) (recyclables, hazardous waste, and other) }\end{array}$ & Changsha and Shijiazhuang \\
$\begin{array}{l}\text { Bisection method (a) (recyclables and nonrecyclables) } \\
\text { Bisection method (b) (dry waste and wet waste) }\end{array}$ \\
\hline
\end{tabular}

Table 2: Classification schemes in Germany, the US, the UK, Sweden, and Japan.

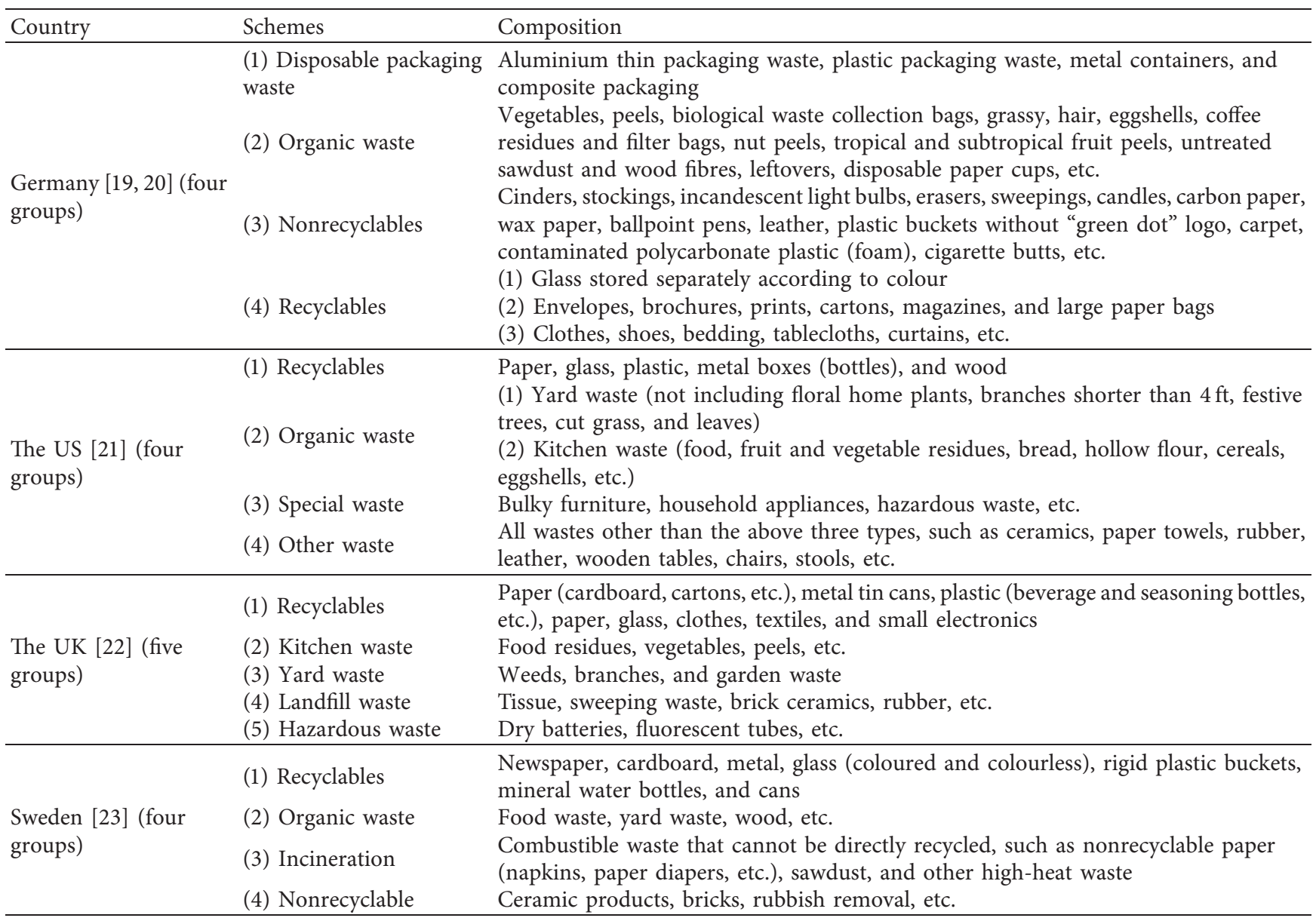


TABLE 2: Continued.

\begin{tabular}{|c|c|c|}
\hline Country & Schemes & Composition \\
\hline \multirow{7}{*}{$\begin{array}{l}\text { Japan [24] (seven } \\
\text { groups) }\end{array}$} & (1) Incineration & $\begin{array}{l}\text { Nonrecyclable paper (napkins, paper diapers, etc.), kitchen waste (leaf leaves, leftovers, } \\
\text { etc.), wood dust, and other waste (wood sticks, cigarette butts, desiccants, pet faeces, } \\
\text { etc.) }\end{array}$ \\
\hline & (2) Plastic bottles & $\begin{array}{l}\text { Plastic containers and packaging marked with a special logo (e.g., plastic bottles for } \\
\text { edible oil, soy sauce, beverages, wine bottles, etc.) }\end{array}$ \\
\hline & (3) Other plastics & $\begin{array}{l}\text { Plastics other than containers and packaging, such as video tapes, compact discs, } \\
\text { laundry pockets, toothbrushes, ballpoint pens, plastic toys, sponges, footwear, etc. }\end{array}$ \\
\hline & (4) Nonincineration & $\begin{array}{l}\text { Ceramics (bowls, casserole dishes, etc.), small appliances (irons, hair dryers, etc.), and } \\
\text { certain necessities (heat-resistant glass, cosmetic bottles, electric bulbs, disposable } \\
\text { heating stoves, disposable lighters, metal bottles, etc.) }\end{array}$ \\
\hline & (5) Recyclables & $\begin{array}{l}\text { Paper (newspapers, leaflets, magazines, advertising paper, cartons, etc.), cloth (old } \\
\text { clothes, old curtains, etc.), metal, and glass (wine, vinegar, soy sauce bottles, beer } \\
\text { bottles, etc.) }\end{array}$ \\
\hline & (6) Hazardous waste & Light sticks, dry batteries, mercury thermometers, etc. \\
\hline & (7) Bulky waste & $\begin{array}{l}\text { Electrical appliances (refrigerators, air conditioners, washing machines, televisions, } \\
\text { etc.), furniture (waste furniture, household appliance cabinets, bedding, induction } \\
\text { cookers, electric heaters, etc.), and other (bicycles, suitcases, etc.) }\end{array}$ \\
\hline
\end{tabular}
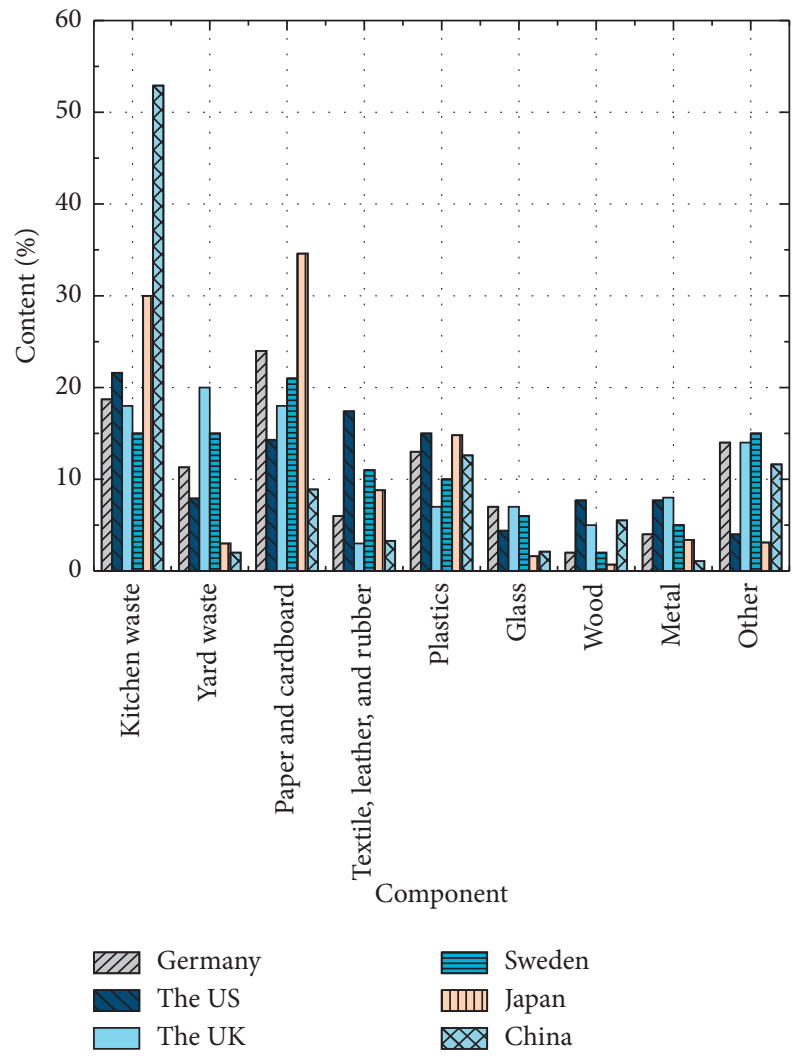

FIGURE 1: MSW composition in Germany, the US, the UK, Sweden, Japan, and China.

economic industries in Zhejiang province. The amount of MSW collected in Zhejiang's cities and towns is 25.7 million tons in 2019.

Food waste also dominates the composition of MSW in Zhejiang. This waste exhibits high moisture content and perishability. Storage or landfill with other materials causes moisture to migrate and the waste to produce pungent smells. Therefore, food waste must be classified into a separate category, namely, "kitchen waste.” Zhejiang's MSW production is large, and existing landfills are overwhelmed. Certain landfills have been filled (e.g., China Yiwu Waste Landfill in Zhejiang), and some are close to being filled (e.g., Hangzhou Tianziling Waste Landfill in Zhejiang). There is an urgent need to reduce the amount of landfilled waste. Therefore, it is necessary to classify waste suitable for incineration into its own category, namely, "incineration," to reduce the amount of landfill waste produced at the source. Recyclables must be organised to prevent these materials from entering waste treatment process plants. This can mitigate the impact on the surrounding environment and increase the economic benefits. Therefore, recyclable waste is classified into one category, namely, "recyclable." Hazardous substances are classified into one category due to their special properties, namely, "hazardous waste." All wastes not included in the above four categories are classified into one category, namely, "other waste." The proposed MSW classification is displayed in Figure 2. "Kitchen waste" primarily includes leftovers, peels and shells, vegetable stalks, leaves, and branches. "Incineration" predominately includes wood (e.g., wooden furniture, wooden decorations, etc.), fabric, plastics, and contaminated paper. "Recyclable" primarily includes uncontaminated paper and cardboard, recyclable textile, metals, leather, rubber, plastic bottles/barrels, plastic packaging, and toughened glass. "Hazardous waste" primarily includes batteries, medical waste, and household/ automotive maintenance. "Other waste" predominately includes all wastes not covered in the abovementioned categories.

The purpose of classification is to reasonably treat different types of MSW. Therefore, ensuring consistency between source separation and waste treatment is at the core of improving waste management. The life cycle of MSW is displayed in Figure 3. Kitchen waste is treated using composting or anaerobic fermentation to obtain usable energy instead of disposing of it in a traditional landfill. Incinerating high water content kitchen waste from China is also advised against, which is consistent with the results obtained by 


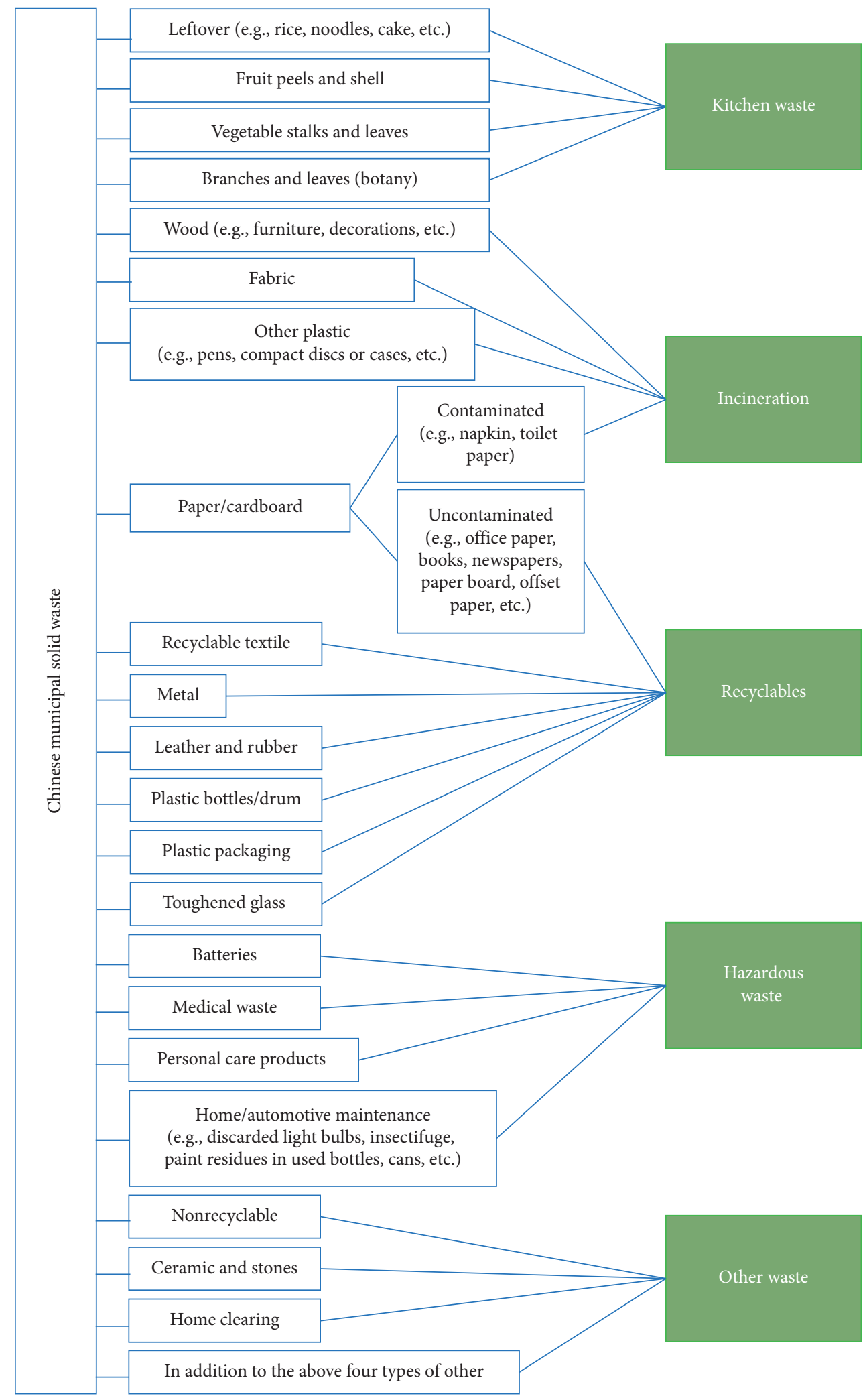

FIgURE 2: Proposed MSW classification.

Yano et al. [32], who found that composting and anaerobically digesting food waste in China can more effectively recycle electricity and heat energy than through incineration alone. However, composting produces leachate, waste residue, and GHGs. The leachate requires special treatment, and the waste residue must be transported to a landfill. 


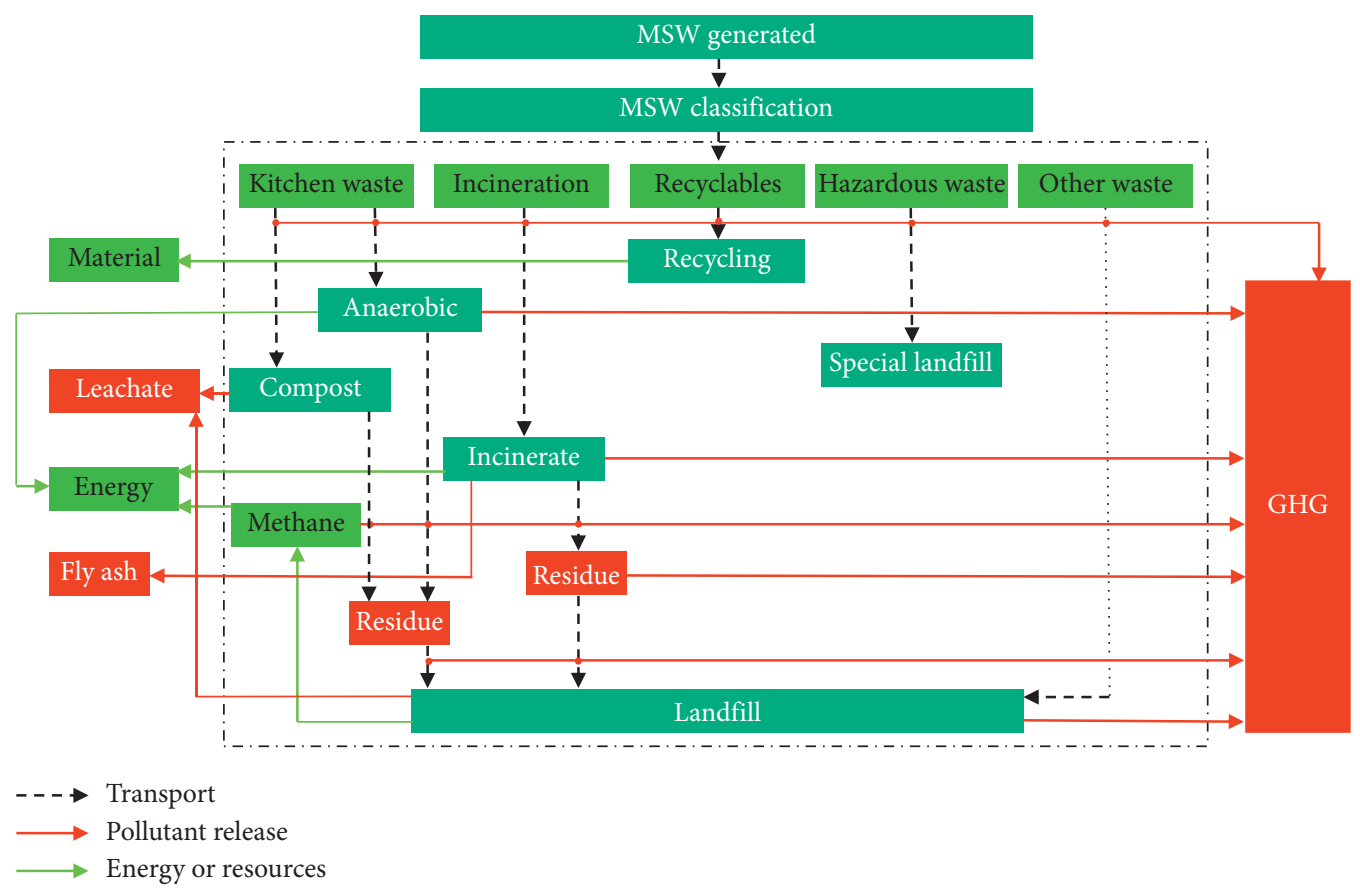

FIGURE 3: Life cycle of classified MSW.

Electric energy can be obtained by incinerating waste. However, incineration produces fly ash, residue, and waste gas. The fly ash must be stabilised with the waste-activated carbon, compacted, and transported to a hazardous waste landfill site. The waste residue is collected and disposed off in the landfill. The waste gas is filtered and discharged after reaching the quality standard. Recyclable waste can be recycled at a resource recycling and processing station to obtain economic benefits. Hazardous waste is treated using a special landfill. This type of waste does not participate in the disposal process of the other wastes to maintain the environmental quality. Other waste is disposed off in landfills, but it produces GHGs and leachate. GHGs are emitted during the entire life cycle process (transportation at the source and transhipment).

\subsection{Method}

2.2.1. Economic Benefit Analysis (EBA). EBA refers to the assessment of the size of economic benefits and analysis on the causes of these benefits. Many scholars use EBA to evaluate waste classification methods. Nie et al. [33] proposed a classification method for waste from Shanghai Pudong, China, analyzed its economic benefits, and determined the most appropriate classification method. Elagroudy et al. [34] divided the economic benefits into two parts, namely, capital and maintenance costs, and analyzed three solid waste management methods in Basra, Iraq.

Economic benefits determine the cost performance of the classification method. Economic benefits primarily include four components: recoverable resource recovery incomes $\left(R_{i}\right)$, WTE utilisation incomes $\left(E_{i}\right)$, MSW operation and management costs $\left(O_{c}\right)$, and MSW treatment project investment costs $\left(T_{c}\right)$.

The benefits of waste disposal can be calculated using the following equation:

$$
I_{t}=R_{i}+E_{i}
$$

where $I_{t}$ is the total income from MSW disposal, $R_{i}$ is the income from recyclables' collection, and $E_{i}$ is the income from WTE.

The cost of waste disposal can be calculated using the following equation:

$$
C_{t}=O_{c}+E_{c} \text {, }
$$

where $C_{t}$ is the total cost from MSW disposal, $O_{c}$ is the cost of the MSW operation and management, and $E_{c}$ is the cost of MSW civil engineering.

The net income (NI) from waste disposal can be calculated using the following equation:

$$
\mathrm{NI}=I_{t}-C_{t},
$$

where NI is the NI from MSW disposal.

The income-cost ratio (ICR) of waste disposal can be calculated using the following equation:

$$
\mathrm{ICR}=\frac{I_{t}}{C_{t}},
$$

where the ICR is the ratio of the total MSW income to the total cost.

2.2.2. Life Cycle Assessment (LCA). LCA is the evaluation of the entire production, process, use, and final disposal cycle of a product or service. This method has been widely 
used in various engineering designs and in research and development. Applying LCA to the classification of MSW can assess the environmental impact by identifying, quantifying, and evaluating the energy, materials, and waste released into the environment [35]. This is helpful for designing source planning, transportation, and end disposal. This method also helps to establish a wholeprocess life cycle management system for waste disposal. The environmental benefits identified by some scholars using LCA to study waste disposal methods are listed in Table 3.

MSW can cause environmental problems throughout its life cycle. During waste storage, waste emits odour and leachate which breeds bacteria. During waste transportation, diesel combustion releases GHGs (e.g., $\mathrm{CO}_{2}$ and $\mathrm{CO}$ ). Additionally, because of the water contained in the waste, transportation, extrusion, and jolting produce leachate that emits odour. Waste disposal produces landfill gas, leachate, GHGs, dioxins, and fly ash that pollute the environment and harm the soil, water, and air. However, these problems can be solved using waste classification to make the waste components for storage, transportation, and treatment more convenient for management, thus reducing pollutant discharge.

In this study, environmental benefits were primarily considered using three indicators. The first is the global warming potential (GWP), which refers to the GHGs (e.g., $\mathrm{CO}_{2}$ and $\mathrm{CH}_{4}$ ) emitted by landfills, composting plants, and incinerators. The second is acidification potential (AP), which primarily refers to acidic substances (e.g., $\mathrm{SO}_{2}, \mathrm{NO}_{x}, \mathrm{H}_{2} \mathrm{~S}, \mathrm{NH}_{3}$, and $\mathrm{HCl}$ ) emitted during processing. Finally, EC is the amount of fossil energy (e.g., diesel and electricity) consumed in transportation, processing, and infrastructure.

\subsubsection{Calculation of Waste Treatment Efficiency.} Reduction refers to the reduction in waste after treatment. For example, landfills occupy a large amount of land resources, while incineration can reduce waste capacity and waste weight by more than 85 and 75\%, respectively. In addition, composting can convert the organic material into a fertiliser and correspondingly reduce the landfill volume. The reduction value can be calculated by multiplying the proportion of the back-end treatment process by the corresponding reduction rate.

Recycling refers to the energy recovery utilisation rate in the treatment process, such as landfill gas power generation, incineration power generation, and composting capacity. It also includes the proportion of recyclable materials.

Harmlessness refers to whether the design method of the treatment site meets the standard required for handling emissions and pollutants. The landfill site design can adopt a combination of physico-chemical pretreatment (e.g., coagulative sedimentation, ammonia nitrogen stripping, and chemical oxidation), biological main body treatment (e.g., anaerobic, anoxic, and aerobic), physico-chemical deep treatment (e.g., adsorption, reverse osmosis, and catalytic oxidation), a leachate recharging method, or mineralised waste biological reaction bed method [45] to stabilise the landfill.

2.2.4. Radar Chart Analysis (RCA). RCA is a type of graph that displays multidimensional data in a two-dimensional form. The analysis and comparison of multiple indices can be presented in the same coordinate system. By applying this method to the MSW classification analysis, the comprehensive ability of each method can be directly reflected. The RCA steps are as follows: (1) set capability indices; (2) evaluate the capability indices of the classification method; (3) classifications can be divided into seven grades (excellent, better, good, medium, general, poor, and very poor) according to the performance evaluation of each classification; and, (4) draw the radar chart.

\section{Result}

3.1. Economy. Economic benefits include direct recovery of materials and energy recovery after treatment. Recyclable resources can generate considerable income through recycling at enterprises or factories after real-time collection and sorting by waste trucks. For example, $850 \mathrm{~kg}$ of paper can be made by recycling $1 \mathrm{t}$ of wastepaper, $300 \mathrm{~kg}$ of wood can be preserved, and $74 \%$ of the associated pollution can be reduced compared with the equivalent production [46]. For every tonne of scrap steel recovered, $0.9 \mathrm{t}$ of steel can be produced, which is $47 \%$ less costly than smelting ore [47]. The WTE income refers to income from incineration, landfill treatment, power generation, and heating. Income can also be generated from composting waste into fertiliser, biogas production, and fuel production. Waste operation and management costs include transportation, electricity, water, labour, material, and equipment maintenance costs [30]. MSW processing engineering investment costs include construction, equipment and facilities, and land occupation costs.

According to equations (1)-(4), the economic benefits of MSW classification methods in various countries were calculated. The income and treatment fee per tonne of waste were also calculated. To illustrate the calculation process, this study is used. Through research, the new method of waste classification and its detailed corresponding components are discussed, leading to changes in the content of various types of waste. Finally, recyclable, kitchen, incineration, hazardous, and other wastes accounted for 20.9, 54.6, 10.5, 6.8, and $7.2 \%$, respectively. The above data was used to multiply the profit (or cost) price to obtain $R_{i}, E_{i}, O_{c}$, and $E_{c}$ and apply them to equations (1)-(4).

The economic benefits of MSW classification used in Germany, the US, the UK, Sweden, Japan, China, and the present study are displayed in Table 4 . China exhibited the highest MSW disposal cost, which was $9.7 \%$ higher than the US, $145.6 \%$ higher than Japan, and $386.4 \%$ higher than Sweden. The NI and ICR were the lowest in China. The reasons for the substantial differences are as follows. First, China exhibited a large MSW output and disposal amount. Second, there were recyclable resources that were not 
TABLE 3: Summary of major MSW management LCA studies.

\begin{tabular}{|c|c|c|c|}
\hline No. & Country & $\begin{array}{l}\text { Parameter impact } \\
\text { assessment }\end{array}$ & Content and results \\
\hline 1 & China [36] & (1) GW & $\begin{array}{l}\text { MSW (55\% moisture content) was studied to compare the differences in GHG emissions in } \\
\text { landfill, compost, anaerobic, and incineration treatments. The results demonstrated that the } \\
\text { four treatments emitted } 197.5,37.7,33.6 \text {, and } 124.3 \mathrm{~kg} \mathrm{CO}_{2} \text { eq./t, respectively. Composting } \\
\text { can avoid the large amount of GHG emissions caused by landfilling primary domestic waste } \\
\text { and can form a carbon sink. Energy recovery and replacement of grid emissions during } \\
\text { anaerobic digestion can significantly reduce GHGs }\end{array}$ \\
\hline 2 & India [37] & $\begin{array}{l}\text { (1) GW } \\
\text { (2) AP } \\
\text { (3) HTP }\end{array}$ & $\begin{array}{l}\text { GHG emissions from wastes subjected and not subjected to resource recovery were } 3.43 E 3 \text { and } \\
4.92 \mathrm{E} 3 \mathrm{kgCO} \text { eq, respectively. Studies have also found that open storage and landfill disposal } \\
\text { of waste emit more GHGs }\left(\mathrm{CH}_{4}\right)\end{array}$ \\
\hline 3 & China [38] & $\begin{array}{l}\text { (1) GW } \\
\text { (2) EC } \\
\text { (3) ER }\end{array}$ & $\begin{array}{l}\text { MSW is the least effective source of direct landfilling for the waste reduction indicators } \\
\text { (stability, resource recovery, energy recycling, and GHG reduction) }\end{array}$ \\
\hline 4 & China [39] & $\begin{array}{l}\text { (1) ER } \\
\text { (2) GW }\end{array}$ & $\begin{array}{l}\text { Paper incineration can produce the most energy }(4,426.04 \mathrm{E} 9 \mathrm{kWh} / \mathrm{a}) \text { followed by plastic } \\
(2,117.95 \mathrm{kWh} / \mathrm{a}) \text {. Additionally, the GHGs released by incineration reached } 874.66 \mathrm{Gg} \mathrm{CO}_{2} \\
\text { eq./a, followed by paper waste incineration }\left(53.92 \mathrm{Gg} \mathrm{CO}_{2} \text { eq./a). Plastic produces } 1 / 2 \text { the }\right. \\
\text { recycled energy of paper, and the GHG emissions from plastic incineration are } 16 \text { times that of } \\
\text { paper }\end{array}$ \\
\hline 5 & China [40] & $\begin{array}{l}\text { (1) GW } \\
\text { (2) AP } \\
\text { (3) EC }\end{array}$ & $\begin{array}{l}\text { There is a correlation between the cost of treatment and environmental emissions, and the } \\
\text { environmental consequences can be minimised by measuring the environmental factors in the } \\
\text { MSW management system }\end{array}$ \\
\hline 6 & Japan [41] & (1) GW & $\begin{array}{l}\text { This study simulates and evaluates an innovative waste management initiative in Kawasaki } \\
\text { using a scenario simulation model based on the LCA approach } \\
\text { The results demonstrate that recycling mixed paper, mixed plastics, and organic wastes and } \\
\text { utilising the recycled materials in industrial production in Kawasaki can potentially reduce } \\
\text { emissions by approximately } 69 \mathrm{kt} \mathrm{CO}_{2} \text { and } 8 \mathrm{kt} \text { incineration ashes from landfill }\end{array}$ \\
\hline 7 & Turkey [42] & (1) GW & $\begin{array}{l}\text { Four scenarios were developed as alternatives to the existing waste management system and } \\
\text { were evaluated for the optimal environmental solution. The scenario with } 75 \% \text { landfilling and } \\
25 \% \text { composting provided the optimal results in terms of human health and environmental } \\
\text { impact. Current emissions from the present MSW facility were estimated for } \mathrm{CH}_{4} \text { and } \mathrm{CO}_{2} \\
\text { emissions. Annual emissions in } 2017 \text { were } 8,674 \text { t/a and } 3,161 \mathrm{t} / \mathrm{a} \text { for } \mathrm{CO}_{2} \text { and } \mathrm{CH}_{4} \text {, } \\
\text { respectively. The estimated ground-level concentrations of these emissions were } 30 \mu \mathrm{g} \mathrm{m}^{-3} \\
\text { and } 50 \mu \mathrm{g} \mathrm{m}^{-3} \text { for } \mathrm{CO}_{2} \text { and } \mathrm{CH}_{4} \text {, respectively }\end{array}$ \\
\hline 8 & Sweden [43] & (1) ER & $\begin{array}{l}\text { The study illustrates that reduced landfilling in favour of increased energy and material } \\
\text { recycling leads to lower environmental impacts, consumption of energy resources, and } \\
\text { economic costs } \\
\text { Landfilling energy-rich waste should be avoided to the extent possible, partly because of the } \\
\text { negative environmental impacts from landfilling, but primarily because of the low recovery of } \\
\text { resources when landfilling. Differences between materials recycling and incineration are small; } \\
\text { but in general, plastic recycling is superior to incineration, and biological treatment is worse }\end{array}$ \\
\hline 9 & $\begin{array}{l}\text { Germany } \\
{[44]}\end{array}$ & $\begin{array}{l}\text { (1) GW } \\
\text { (2) ER }\end{array}$ & $\begin{array}{l}\text { The impact of heating systems on the overall result was significant. The efficiency of heat } \\
\text { production was extremely high for all incinerators, and the utilisation was } 100 \% \text {. Meanwhile, } \\
\text { the combined biogas and composting plant only utilised } 21 \% \text { of the heat produced due to a } \\
\text { lack of capacity (supply) in the current heating system. Recommendations for the systems } \\
\text { include a reduction in ammonia emissions from biogas plants, which can improve the overall } \\
\text { environmental performance of the German system }\end{array}$ \\
\hline
\end{tabular}

Note: AP: Acidification Potential, EC: Energy Consumption, ER: Energy Recovery, HTP: Human Toxicity Potentials, and GW: Global Warming.

effectively recycled, lowering the resource recycling income. Third, the classification in China did not fully consider the connection with the waste treatment process, and there was a lack of incineration, composting, and other treatment methods to increase revenue. Fourth, the landfill treatment was heavily relied on. The low efficiency of landfills led to a high treatment cost. The MSW classification method in this study improved the income from resource and energy recovery, updated the waste treatment share by increasing incineration and composting and reducing landfilling, and reduced the project investment cost. Compared with the present method used in China, the method proposed in this study reduced the processing cost by $69.3 \%$ and increased NI by $69.4 \%$, which were comparable with the UK, and the ICR increased by $440 \%$, which was comparable to the UK and Sweden. Table 5 also shows that the overall NI was negative for the current management method. To increase the economic benefits and achieve an income and expenditure balance, charging for waste and coordinating with the government to receive subsidies are recommended. 
TABLE 4: Economic benefits of MSW classification in Germany, the US, the UK, Sweden, Japan, China, and the study.

\begin{tabular}{|c|c|c|c|c|c|c|c|}
\hline Economic benefit & Germany & The US & The UK & Sweden & Japan & China & Present study \\
\hline MSW output (mt) & 51.1 & 258.5 & 26.4 & 4.4 & 43.0 & 204.0 & 25.7 \\
\hline$R_{i}(\mathrm{M}$ dollars $)$ & 949.6 & $1,899.4$ & 203.7 & 44.7 & 59.0 & 88.8 & 155.8 \\
\hline$E_{i}$ (M dollars) & 295.8 & $1,064.1$ & 152.8 & 72.9 & 308.5 & 104.8 & 198.4 \\
\hline$I_{t}(\mathrm{M}$ dollars $)$ & $1,245.4$ & $2,963.5$ & 356.5 & 117.6 & 367.5 & 193.6 & 354.2 \\
\hline$O_{c}(\mathrm{M}$ dollars $)$ & 198 & 1,584 & 170 & 46 & 743 & 1,645 & 67 \\
\hline$E_{c}$ (M dollars) & 725,805 & $6,100,177$ & 393,996 & 168,901 & $2,725,841$ & $6,695,400$ & 259,882 \\
\hline$C_{t}(\mathrm{M}$ dollars $)$ & 729,003 & $6,101,761$ & 394,166 & 168,947 & $2,726,584$ & $6,697,045$ & 259,949 \\
\hline NI (M dollars) & $-727,758$ & $-6,098,798$ & $-393,810$ & $-168,829$ & $-2,726,217$ & $-6,696,851$ & $-259,594$ \\
\hline ICR $\left(10^{-4}\right)$ & 17.2 & 4.9 & 9.0 & 7.0 & 1.3 & 0.3 & 13.6 \\
\hline
\end{tabular}

Note. Recyclable resource material income is $\$ 29 / \mathrm{t}$. Reaching fertiliser standard resource income is $\$ 8 / \mathrm{t}$. Revenue from incineration power supply is $\$ 32 / \mathrm{t}$. Landfill cost is $\$ 6 / t$. Incineration treatment cost is $\$ 21 / t$. Landfill project investment is $\$ 25,730 /$ t. Incineration plant project investment is $\$ 78,623 / t$ [30].

TABle 5: Life cycle inventories in the operation stage of each scenario (per tonne of dry waste).

\begin{tabular}{|c|c|c|c|}
\hline Waste treatment method & Category & Pollutants & Emissions \\
\hline \multirow{11}{*}{ Landfill } & \multirow{5}{*}{ Material consumption } & Diesel & $2.388 \mathrm{~L}$ \\
\hline & & Electricity consumption & $0.42 \mathrm{kWh}$ \\
\hline & & Energy recovery & $-111.92 \mathrm{kWh}$ \\
\hline & & Water & $0.047 \mathrm{~m}^{3}$ \\
\hline & & Sand & $0.41 \mathrm{~m}^{3}$ \\
\hline & \multirow{6}{*}{ Direct gas emissions } & $\mathrm{CH}_{4}$ & $233 \mathrm{~kg}$ \\
\hline & & $\mathrm{CO}_{2}$ & $94.8 \mathrm{~kg}$ \\
\hline & & $\mathrm{SO}_{2}$ & $0.8 \times 10^{-2} \mathrm{~kg}$ \\
\hline & & $\mathrm{NO}_{x}$ & $4.44 \times 10^{-2} \mathrm{~kg}$ \\
\hline & & $\mathrm{H}_{2} \hat{\mathrm{S}}$ & $0.29 \times 10^{-2} \mathrm{~kg}$ \\
\hline & & $\mathrm{NH}_{3}$ & $1.09 \times 10^{-2} \mathrm{~kg}$ \\
\hline \multirow{7}{*}{ Incineration } & \multirow{4}{*}{ Material consumption } & Diesel & $6.87 \mathrm{~L}$ \\
\hline & & Electricity consumption & $152.73 \mathrm{kWh}$ \\
\hline & & Energy recovery & $-696.84 \mathrm{kWh}$ \\
\hline & & Water & $0.23 \mathrm{~m}^{3}$ \\
\hline & \multirow{3}{*}{ Direct gas emissions } & $\mathrm{SO}_{2}$ & $1.69 \mathrm{~kg}$ \\
\hline & & $\mathrm{NO}_{x}$ & $3.39 \times 10^{-1} \mathrm{~kg}$ \\
\hline & & $\mathrm{NH}_{3}$ & $1.84 \mathrm{~kg}$ \\
\hline \multirow{8}{*}{ Compost } & \multirow{4}{*}{ Energy consumption } & Diesel & $1.75 \mathrm{~L}$ \\
\hline & & Electricity & $19 \mathrm{kWh}$ \\
\hline & & $\mathrm{CO}_{2}$ & $0.678 \mathrm{~kg}$ \\
\hline & & $\mathrm{SO}_{2}$ & $0.07 \mathrm{~kg}$ \\
\hline & \multirow{4}{*}{ Direct gas emissions } & $\mathrm{NO}_{x}$ & $4.29 \times 10^{-2} \mathrm{~kg}$ \\
\hline & & $\mathrm{H}_{2} \mathrm{~S}$ & $0.04 \times 10^{-2} \mathrm{~kg}$ \\
\hline & & $\mathrm{NH}_{3}$ & $0.99 \times 10^{-3} \mathrm{~kg}$ \\
\hline & & $\mathrm{HCl}$ & $1.36 \times 10^{-2} \mathrm{~kg}$ \\
\hline
\end{tabular}

3.2. Environment. The impacts of landfill, incineration, composting, and other major treatment methods on the GWP, AP, and EC are displayed in Figure 4 [48-51], and life cycle inventories in the operation stage of each scenario are displayed in Table 5 [48-51]. Environmental benefits were mainly related to the emissions and energy produced during the treatment process. Diesel consumption and transportation exhibited little impact on the environmental benefits, while electricity generation contributed the most. Landfills produced substantially higher levels of GHG than those of the other treatments, which was primarily a result of their direct emissions $\left(233 \mathrm{~kg} \mathrm{CO}_{2} \mathrm{eq}\right)$. Incineration was effective for power recovery $(-696.84 \mathrm{kWh} / \mathrm{t} \mathrm{MSW})$, which indirectly reduced GHG emissions. Although composting has no power recovery capacity, the acid content of the compost $(0.1 \mathrm{~kg})$ is much lower than that of incineration $(3.9 \mathrm{~kg})$.

The emissions and production capacities of various waste classification methods are displayed in Table 6. The Chinese classification method of GHG emissions reached $825.9 \mathrm{kt}$, AP emissions were $6.7 \mathrm{kt}$, and the energy consumption reduction was the lowest at $-1.029 E 9 \mathrm{~kW}$. The primary factor affecting the environment was the waste treatment process. In this study, the waste treatment process was improved to reduce the amount of incoming waste, such as using composting for kitchen waste instead of landfills. The incineration and composting capacities increased, and the landfill capacity was reduced, shifting from GHG emissions to GHG absorption $(-787.2 \mathrm{kt})$. Additionally, incineration produced electricity, which reduced energy 


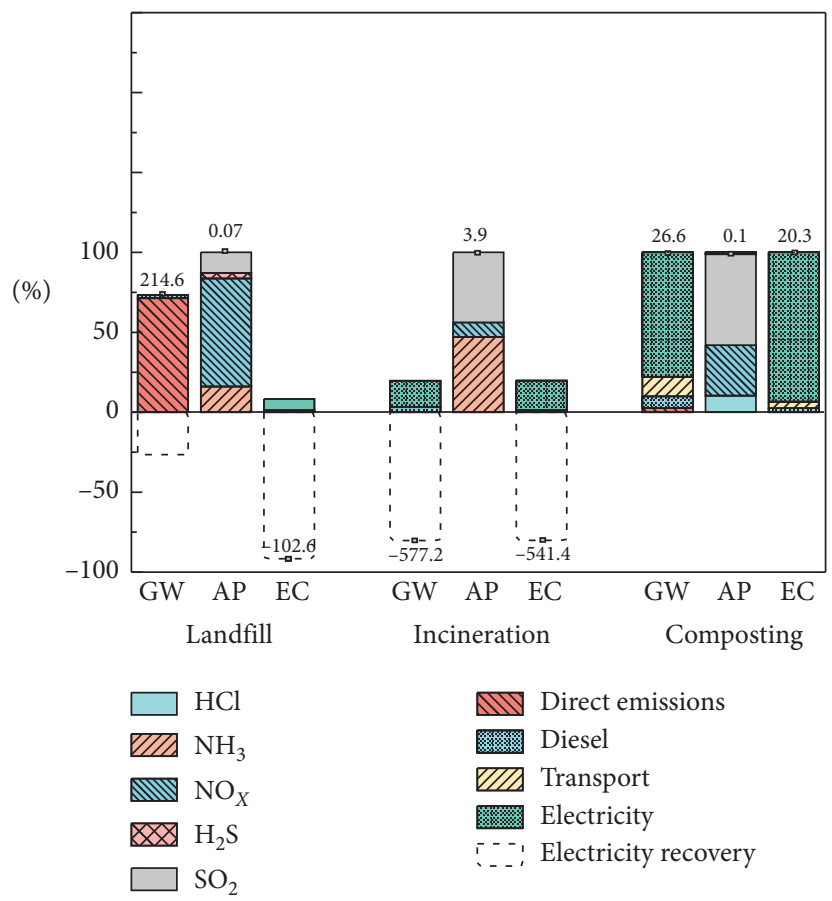

Figure 4: Contributions to landfill, incineration, and composting processes (units: GW-kg/t MSW; AP-kg/t MSW; EC-kWh/t MSW).

TABLE 6: Emissions and capacities of waste classification methods in each country.

\begin{tabular}{lccccccc}
\hline & Germany & The US & The UK & Sweden & Japan & China & Study \\
\hline Output (mt) & 51.1 & 258.5 & 26.4 & 4.4 & 43.0 & 204.0 & 25.7 \\
GW (kt) & -519.5 & $2,419.7$ & 108.2 & -118.1 & $-1,979.6$ & $1,725.4$ & 12.5 \\
AP (kt) & 3.62 & 10.1 & 1.5 & 0.8 & 13.5 & -787.2 \\
EC (kWh) & -4980.9 & $-12,019.1$ & -1840.8 & -1124.8 & -6892.0 & -2100.6 & 1.2 \\
Output* (mt) & 100 & 100 & 100 & 100 & 100 & 100 & -1366.0 \\
GW (kt) & -990.0 & 413.7 & 935.1 & -2718.2 & -4587.9 & 352.9 & -3070.1 \\
AP (kt) & 7.1 & 5.4 & 3.9 & 19.0 & 31.4 & 4.7 \\
EC (kWh) & $-9.745 E 9$ & $-6.930 E 9$ & $-4.656 E 9$ & $-25.88 E 9$ & $-16.03 E 9$ & $-1.029 E 9$ & $-5.327 E 9$ \\
\hline
\end{tabular}

Note: "-" means a reduction in gas emission or energy saved. Orange and blue represent the worst and best performance, respectively; *: unify the output variable.

consumption 5.2 fold. These figures were similar to those of the UK $(-5.327 E 9$ and $-4.656 E 9$, respectively). This study significantly improved the MSW classification environmental benefits compared with those of the present classification methods used in China.

\subsection{Waste Treatment Efficiency}

3.3.1. Reduction. Based on the amount of incineration and compost, equation (5) was used to calculate the MSW reduction degree under each plan. Table 7 [7, 22, 52-56] summarizes the MSW reduction data. By updating the classification method, the reduction rate of the landfill volume in this study has been increased from $16 \%$ to $63.4 \%$. This is because the proportion of incineration and composting treatment has been increased through classification (the replacement of landfill with compost and incineration can reduce $95 \%$ and $85 \%$ of kitchen waste, respectively), thereby reducing landfill volume:

$$
\eta_{m}(\%)=\frac{\left(m_{T}-m_{I}-m_{C}\right)}{m_{T}},
$$

where $\eta_{m}$ is the reduction rate after waste classification, $m_{T}$ is the total amount of waste that enters the treatment field, $m_{I}$ is the amount of waste incineration, and $m_{C}$ is the amount of waste composting.

3.3.2. Recycling. The recycling assessment was based on the recovery rates of resources and energy, and the results are displayed in Table 8. The current classification method used in China uses landfills to treat most of the waste, resulting in a low resource recycling rate. Moreover, waste entering the incineration plant was not classified, and its complex composition led to a low energy output rate. This study overcame these problems and refined the classification of waste to increase the resource recovery rate from 1.5 to $20.9 \%$ and the energy recovery rate from 1.9 to $65 \%$. 
TABLE 7: Reduction in MSW.

\begin{tabular}{lccccccc}
\hline Country & Germany & The US & The UK & Sweden & Japan & China & Study \\
\hline Reduction (\%) & 92 & 24.6 & 38.6 & 84.5 & 81.9 & 16 & 63.4 \\
\hline
\end{tabular}

TABle 8: Recycling energy and resource recovery rates.

\begin{tabular}{lccc}
\hline Country and references & Resource recovery (\%) & Energy recovery (\%) & Note \\
\hline Germany [57] & 65.0 & 18.0 & (a) Incineration (18.0\%) \\
The US [52] & 25.7 & 12.8 & (a) Incineration (12.8\%) \\
The UK [53] & 27.0 & 8.6 & (a) Incineration (8.6\%) \\
Sweden [23, 58] & 35.6 & 61.6 & (a) Compost (13.3\%) \\
Japan [7] & & & (b) Incineration (48.3\%) \\
China [56] & 4.8 & 29.6 & (a) Energy treatment (9.6\%) \\
Study & 1.5 & 1.9 & (b) Incineration (20.0\%) \\
& 20.9 & 65.0 & (a) Incineration (1.9\%) \\
(a) Incineration (10.5\%) & (b) Compost (54.5\%) \\
\hline
\end{tabular}

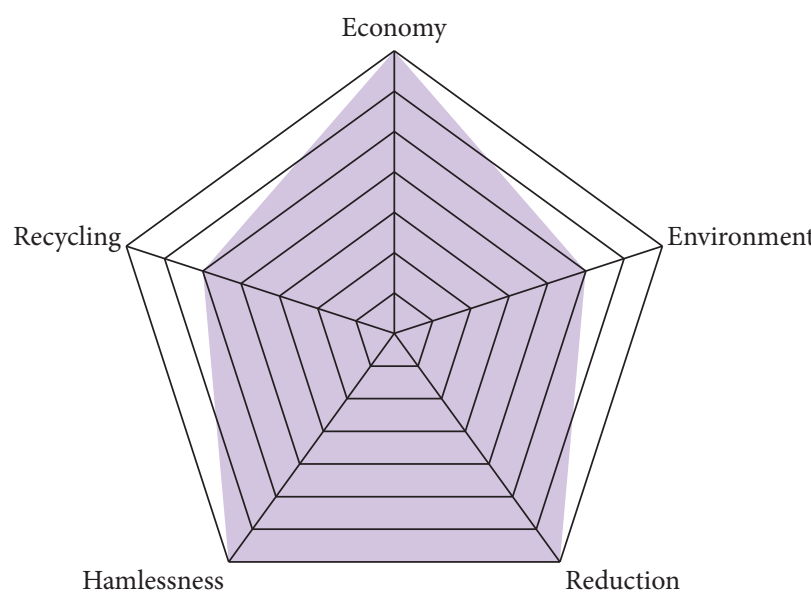

(a)

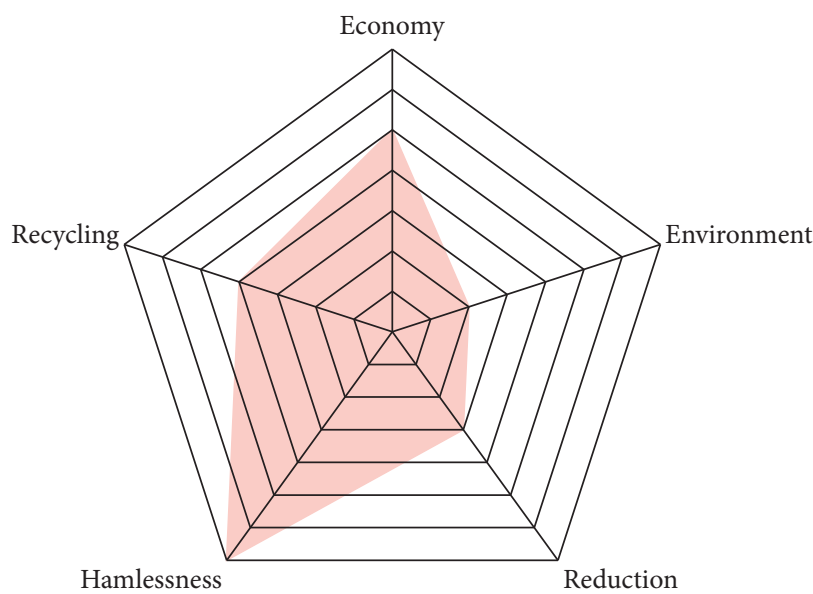

(c)

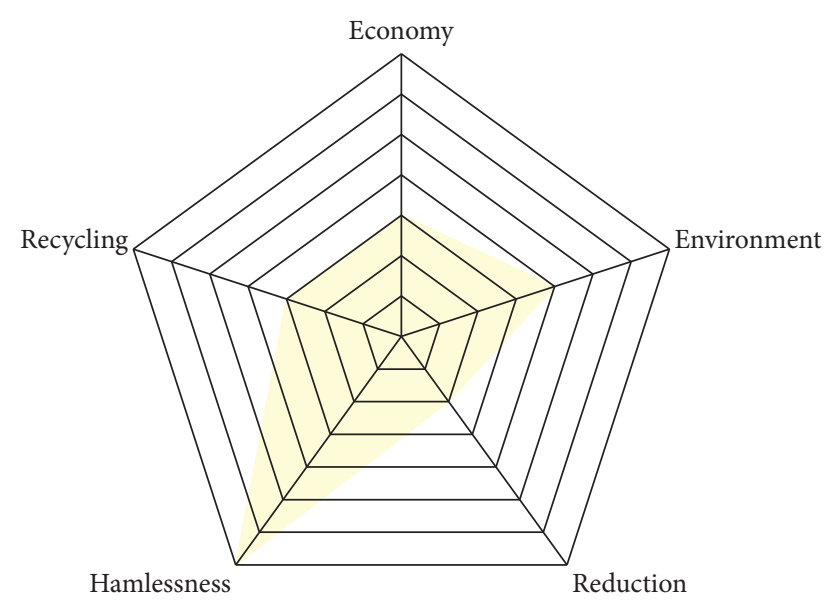

(b)

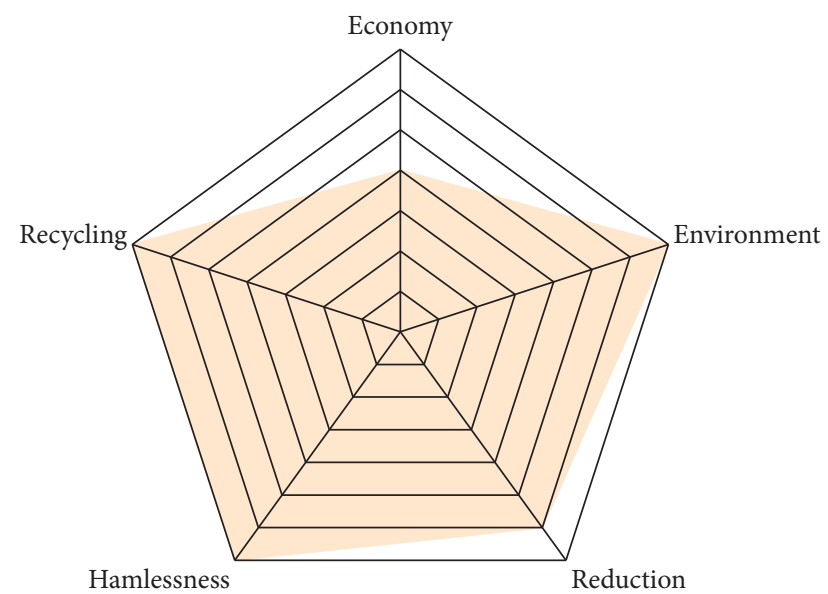

(d)

FIgURE 5: Continued. 


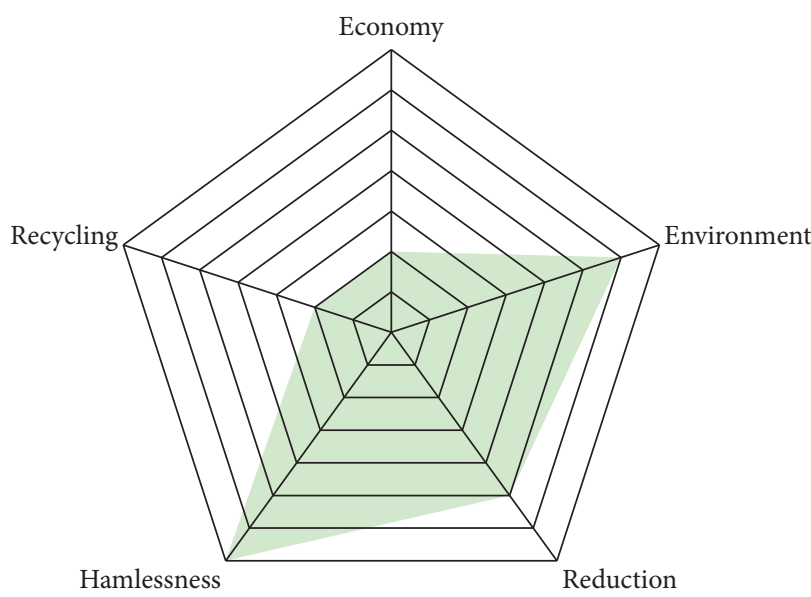

(e)

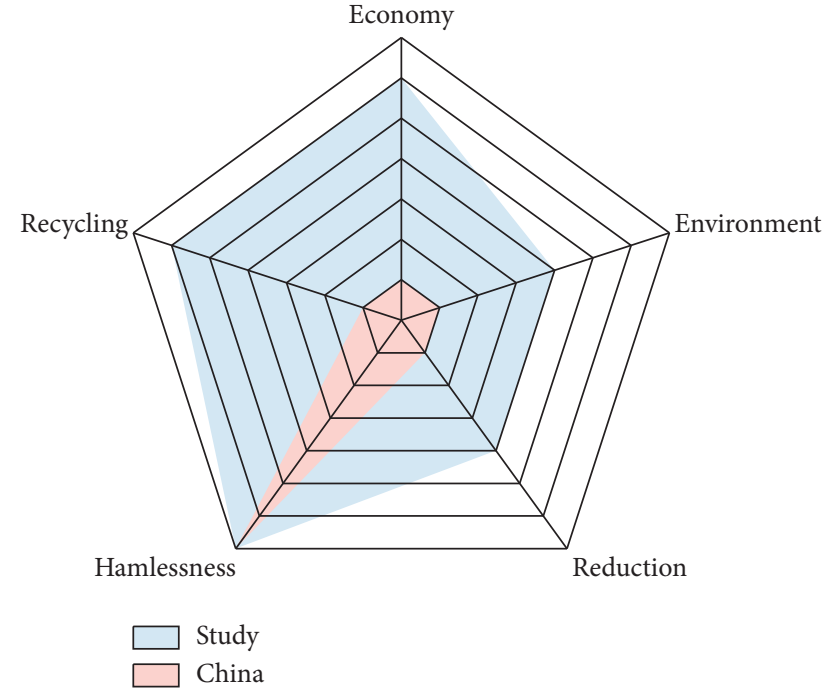

(f)

FIgUre 5: Comprehensive ability comparison in (a) Germany, (b) the US, (c) the UK, (d) Sweden, (e) Japan, and (f) China and the study.

3.3.3. Harmlessness. The harmlessness index judging standard determines whether the design, construction, and final use of the treatment plant meet the national standards. Therefore, although various classification methods are different, MSW treatment plants from various countries will be set up in accordance with pollution-free standards. Therefore, the harmlessness standard is set according to the same evaluation level.

3.4. Comprehensive Evaluation. A radar chart is used to assess the comprehensive ability of MSW classification methods, as displayed in Figure 5. The proposed classification method (Figure 5(f)) and the existing classification methods in China are improved in each index based on the following aspects:

(1) The economic benefit criterion is reflected in the ICR. The economic performance of each country classification method is ranked as follows: Germany (excellent), this study (better), the UK (good), Sweden (medium), the US (general), Japan (poor), and China (urgent need for improvement). In this study, the economic indicators were upgraded by five ratings and became comparable to Germany. The poor performance of the Chinese economic indicators is due to the large waste production, low resource recovery rate, and landfill-based treatment methods in China. This study improves the current waste classification method, increases the integration rate of resource waste, and reduces the amount of waste disposed off in landfills.

(2) The average values for the assessment criteria for environmental benefits, GWP, AP, and EC, are calculated (weight is 1 ). The environmental benefits of each classification method are ranked as follows:
Sweden (excellent), Japan (better), Germany (good), the US and this study (medium), and China (urgent need for improvement). In this study, the environmental indicators were upgraded by two ratings and became comparable to the US. This study proposed the improvement of the purity of incoming waste, increasing incineration to generate electricity, reducing $\mathrm{CO}_{2}$ emissions from conventional power generation, and reducing energy consumption, thus reducing environmental pollution.

(3) The reduction assessment results can be found in Table 7. In this study, the reduction index was improved by three ratings, becoming comparable to Japan. This is primarily due to an increase in the total amount of incineration and composting by up to $65 \%$.

(4) The recycling assessment results are displayed in Table 8 . In this study, the resource recovery index improved by five levels, becoming comparable to Sweden. The predominate reason for this is that resource waste was effectively classified for incineration and composting.

\section{Conclusion}

This paper compares domestic and foreign waste classification schemes and quantitatively analyzes the benefits of each classification scheme. The factors that need to be considered in the formulation of waste classification schemes can also be considered from these benefits. This study developed a new method for the classification of MSW in Zhejiang, China, that divides MSW into five categories: kitchen waste, incineration, recyclables, hazardous waste, and other waste. The proposed classification method considers the relationship between source classification and waste treatment, such as separating kitchen 
waste for composting. Additionally, combustible and harmless materials can undergo incineration treatment, recyclables can be used for resource recycling, hazardous waste (poisonous and harmful materials) can be disposed off in special landfills, and other wastes can be disposed off in traditional landfills. If only one classification method is designed and the front and back ends are not matched, the performance is still poor in all aspects. The existing waste classification methods in six countries were compared and analyzed in the study through data collection, calculations, EBA, and LCA, which were utilised to establish the radar chart of each classification method. The classification method presented in this study improved the original Chinese methods by five (economic), two (environmental), three (reduction), and five (recycle) levels. Considering the substantial project investment cost required for waste treatment, incurring a reasonable waste treatment fee or utilising government subsidies is recommended. At present, the effectiveness of each classification is studied in a quantitative way, which has certain limitations. Future research can study the benefits under dynamic changes.

\section{Data Availability}

The data used to support the findings of this study are included within the article.

\section{Conflicts of Interest}

The authors declare that they have no conflicts of interest regarding the publication of this paper.

\section{Acknowledgments}

This work was funded by the National Natural Science Foundation of China (Contract nos. 51978625 and 51678532) and Natural Science Foundation of Zhejiang Province, China (Contract no. LZ21E080003) and supported by the Fundamental Research Funds of Zhejiang Sci-Tech University.

\section{References}

[1] National Bureau of Statistics of The People's Republic of China, China Statistic Yearbook 2019, 2020, https://www. stats.gov.cn/tjsj/ndsj/2019/indexch.htm.

[2] L. Chen, G. Wu, Y. Zhang, and Y. B. Zhang, "The research status and critical problem of the waste classified recovery behavior," Ecological Economy, vol. 28, no. 2, pp. 142-145, 2012.

[3] A. O. Landva and J. I. Clark, "Geotechnics of waste fill," in Geotechnics of Waste Fills-Theory and Practice, ASTM STP 1070, A. Landva and D. Knowles, Eds., American Society for Testing and Materials, Philadelphia, PA, USA, 1990.

[4] S. Thomas, A. A. Aboura, J. P. Gourc et al., "An in situ waste mechanical experimentation on a French landfill," in Proceedings of the Sardinia 99, Seventh International Waste Management and Landfill Symposium, Cagliari, Italy, October 1999.
[5] M. Sharholy, K. Ahmad, G. Mahmood, and R. C. Trivedi, "Municipal solid waste management in Indian cities-a review," Waste Management, vol. 28, no. 2, pp. 459-467, 2008.

[6] E. Gentil, J. Clavreul, and T. H. Christensen, "Global warming factor of municipal solid waste management in Europe," Waste Management \& Research: The Journal for a Sustainable Circular Economy, vol. 27, no. 9, pp. 850-860, 2009.

[7] H. Y. Zhang, Q. Y. Yang, and G. X. Li, "The comprehensive treatment pattern of municipal solid waste (MSW) based on category classification of Beijing," Applied Mechanics and Materials, vol. 295-298, pp. 1696-1700, 2013.

[8] H. Zhou, Y. Long, A. Meng, Q. Li, and Y. Zhang, "Classification of municipal solid waste components for thermal conversion in waste-to-energy research," Fuel, vol. 145, no. 1, pp. 151-157, 2015.

[9] N. B. Chang and A. Pires, "Technology matrix for solid waste management," Sustainable Solid Waste Management, vol. 1997, 2015.

[10] B. Gu, S. Jiang, H. Wang et al., "Characterization, quantification and management of China's municipal solid waste in spatiotemporal distributions: a review," Waste Management, vol. 61-67, 2016.

[11] M. Liikanen, O. Sahimaa, and M. Hupponen, "Updating and testing of a Finnish method for mixed municipal solid waste composition studies," Waste Management, vol. 52, no. 7, pp. 25-33, 2016.

[12] O. Dada and C. Mbohwa, "Energy from waste: a possible way of meeting goal 7 of the sustainable development goals," Materials Today Proceedings, vol. 5, no. 4, pp. 10577-10584, 2018.

[13] F. Girotto, "A glance at the world," Waste Management, vol. 72, pp. 1-3, 2018.

[14] A. T. T. Al-Hameedi, H. H. Alkinani, H. W. Albazzaz, S. Dunn-Norman, and M. M. Alkhamis, "Insights into the applications of waste materials in the oil and gas industry: state of the art review, availability, cost analysis, and classification," Journal of Petroleum Exploration and Production Technology, vol. 10, no. 5, pp. 2137-2151, 2020.

[15] B. Chen, "Sorting method of municipal domestic waste," Environmental Sanitation Engineering, vol. 22, no. 5, pp. 77-78, 2014.

[16] R. Liu, Z. Li, F. Jiang, and T. Yin, "Study on optimization of urban domestic waste government and evaluate under the background of mandatory classification," Evaluation \& Management, vol. 17, no. 3, pp. 1-7, 2019.

[17] H. Wang, "The realization path exploration of urban household garbage classification based on classification standard," Quality and Technical Supervision Research, vol. 1, pp. 15-19, 2020.

[18] X. Liu, W. Wang, and Y. Shi, "Pilot-scale anaerobic co-digestion of municipal biomass waste and waste activated sludge in China: effect of organic loading rate," Waste Management, vol. 32, no. 11, pp. 2056-2060, 2012.

[19] L. Zhang, "Enlightenment of reduction and separation management of municipal solid waste in Germany," Environmental Sanitation of Engineering, vol. 26, no. 6, pp. 5-6, 2018.

[20] R. Luo and Y. Zhang, "Study on classification method of municipal solid waste in Germany," China Resources Comprehensive Utilization, vol. 26, no. 7, pp. 30-31, 2008.

[21] Y. Gao, H. Chen, and Y. Zhao, "Analysis domestic and foreign municipal solid waste classification methods and classification principles," Environmental Engineering, vol. 35, pp. 242-249, 2017. 
[22] R. Zhang, C. Feng, and J. Chen, "Management and treatment of municipal solid waste in England (part 1)," Energy Conservation and Environmental Protection, vol. 28, no. 5, pp. 29-31, 2010.

[23] G. Gao and Z. Wei, "Sweden's achievements in waste classification for China's reference and inspiration," Logistic Engineering and Management, vol. 9, no. 38, pp. 97-100, 2016.

[24] SANWA, 2018, https://www.sanwa-sng.com.cn/doc/news27. html.

[25] D. Kourkoumpas, S. Karellas, S. Kouloumoundras, G. Koufodimos, P. Grammelis, and E. Kakaras, "Comparison of waste-to-energy processes by means of life cycle analysis principles regarding the global warming potential impact: applied case studies in Greece, France and Germany," Waste and Biomass Valorization, vol. 6, no. 4, pp. 605-621, 2015.

[26] S. Liu, "Current status of municipal solid waste disposal in the United States and its enlightenment to China," Environment and Sustainable Development, vol. 3, pp. 84-86, 2017.

[27] S. Mühle, I. Balsam, and C. R. Cheeseman, "Comparison of carbon emissions associated with municipal solid waste management in Germany and the UK," Resources, Conservation and Recycling, vol. 54, no. 11, pp. 793-801, 2010.

[28] J. Wu, D. Franzén, and M. E. Malmström, "Anthropogenic phosphorus flows under different scenarios for the city of Stockholm, Sweden," Science of the Total Environment, vol. 542, pp. 1094-1105, 2016.

[29] Q. Sun and N. Liu, "Analysis on typical case of garbage classification and exploration of new idea," Environmental Science and Management, vol. 42, no. 7, pp. 167-171, 2017.

[30] P. F. Li, Study on Evaluation of Municipal Solid Waste Disposal Technologies and Enhancement in Classification, Harbin Institute of Technology, Harbin, China, 2016.

[31] H. Yuan, L. A. Wang, F. Su, and G. Hu, "Urban solid waste management in Chongqing: challenges and opportunities," Waste Management, vol. 26, pp. 1052-1062, 2006.

[32] J. Yano and S. I. Sakai, "Waste prevention indicators and their implications from a life cycle perspective: a review," Journal of Material Cycles and Waste Management, vol. 18, no. 1, pp. 1-19, 2015.

[33] Y. Nie, Y. Wu, J. Zhao et al., "Is the finer the better for municipal solid waste (MSW) classification in view of recyclable constituents? A comprehensive social, economic and environmental analysis," Waste Management, vol. 79, pp. 472-480, 2018.

[34] S. Elagroudy, T. Elkady, and F. Ghobrial, "Comparative cost benefit analysis of different solid waste management scenarios in Basrah, Iraq," Journal of Environmental Protection, vol. 2, pp. 555-563, 2011.

[35] M. A. Curran, "The status of life-cycle assessment as an environmental management tool," Environmental Progress, vol. 23, pp. 277-283, 2004.

[36] G. Liu, Y. Hao, L. Dong, Z. Yang, Y. Zhang, and S. Ulgiati, “An energy-LCA analysis of municipal solid waste management," Resources, Conservation, and Recycling, vol. 120, pp. 131-143, 2017.

[37] P. Yadav and S. R. Samadder, "A global prospective of income distribution and its effect on life cycle assessment of municipal solid waste management: a review," Environmental Science and Pollution Research, vol. 24, pp. 1-19, 2017.

[38] Y. L. Liu, P. X. Xing, and J. Liu, "Environmental performance evaluation of different municipal solid waste management scenarios in China," Resources, Conservation and Recycling, vol. 125, pp. 98-106, 2017.
[39] Y. C. Chen, "Evaluating greenhouse gas emissions and energy recovery from municipal and industrial solid waste using waste-to-energy technology," Journal of Cleaner Production, vol. 193, pp. 262-269, 2018.

[40] P. Li, Y. P. Li, G. H. Huang, and J. L. Zhang, "Modeling for waste management associated with environmental-impact abatement under uncertainty," Environment Science \& Pollution Research, vol. 22, no. 7, pp. 5003-5019, 2015.

[41] Y. Geng, F. Tsuyoshi, and X. D. Chen, "Evaluation of innovative municipal solid waste management through urban symbiosis: a case study of Kawasaki," Journal of Cleaner Production, vol. 18, pp. 993-1000, 2010.

[42] A. Y. Cetinkaya, L. Bilgili, and S. L. Kuzu, "Life cycle assessment and greenhouse gas emission evaluation from Askaray solid waste disposal facility," Air Quality, Atmosphere \& Health, vol. 11, no. 5, pp. 549-558, 2017.

[43] O. Eriksson, M. C. Reich, B. Frostell et al., "Municipal solid waste management from a systems perspective," Cleaner Production, vol. 13, no. 3, pp. 241-252, 2005.

[44] M. B. Jensen, J. Moller, and C. Scheulz, "Comparison of the organic waste management systems in the Danish-German border region using life cycle assessment (LCA)," Waste Management, vol. 49, pp. 491-504, 2016.

[45] M. Zhang, X. Shan, K. Li, C. Zhang, F. Zhang, and H. Rong, "Status quo and management countermeasures of municipal solid waste treatment technology," Ecology and Environmental Sciences, vol. 389-396, 2011.

[46] G. Xu and D. Liu, "Basic circular economy and municipal solid waste recycling and recycling countermeasures," in Proceedings of the 2006 Annual Conference of Chinese Society of Environmental Sciences, Jiangshu, China, December 2006.

[47] L. Wang and S. Wu, "Present situation and countermeasures of domestic garbage disposal in rural places of China," China Environmental Management, vol. 3-5, 2011.

[48] B. Wei, J. Wang, K. Tahara, K. Kobayashi, and M. Sagisaka, "Life cycle assessment on disposal methods of municipal solid waste in Suzhou," China Population, Resources and Environment, vol. 19, pp. 93-97, 2009.

[49] J. Hong, X. Li, and Z. Cui, "Life cycle assessment of four municipal solid waste management scenarios in China," Waste Management, vol. 30, no. 11, pp. 2362-2369, 2010.

[50] D. F. Ji, Life Cycle Assessment and Environmental Economic Estimate of Municipal Solid Waste Disposal-Take Beijing City for Instance, Beijing University of Chemical Technology, Beijing, China, 2010.

[51] T. He, L. Hua, Z. Xu, and Z. Zhang, "Influence of urban waste compost and compound fertilizer based on waste compost on flux of $\mathrm{CO}_{2}$ and $\mathrm{CH}_{4}$ from agricultural soils," Journal of Agro-Environment Science, vol. 26, no. 3, pp. 1153-1158, 2007.

[52] L. Zhang, "Enlightenment of reduction and separation management of municipal solid waste in Germany," Environmental Sanitation Engineering, vol. 26, no. 6, pp. 5-8, 2018.

[53] S. Liu, "Current status of urban municipal waste disposal in the United States and its enlightenment," Environment and Sustainable Development, vol. 11, no. 3, pp. 84-86, 2017.

[54] Y. Guo, "Study on waste strategy and waste reduction in the United Kingdom," China Academic Journal Electronic Publishing House, vol. 8, no. 9, pp. 41-44, 2015.

[55] P. Xiao, "Measures of reducing waste in Sweden and their enlightenment to my country," Recyclable Resources and Circular Economy, vol. 11, no. 3, pp. 40-44, 2018. 
[56] H. Xu, "Overview of the development of urban household garbage disposal industry in 2017," China Environmental Protection Industry, vol. 7, pp. 5-9, 2017.

[57] European Commission: Energy and Environmental Statistics, 2020, https://epp.eurostat.ec.europa.eu/portal/page/portal/ eurostat/home/.

[58] H. Xiang, "Recycling and treatment of municipal solid waste in Sweden and its enlightenment," Energy Conservation and Environmental Protection, vol. 30, no. 9, pp. 52-55, 2012. 